\title{
Conservation and use of elm genetic resources in France: results and perspectives $^{\left({ }^{(}\right)}$
}

\author{
Eric Collin ${ }^{(1-4)}$, \\ Michel Rondouin ${ }^{(2)}$, \\ Cécile Joyeau ${ }^{(1)}$, \\ Stéphane Matz ${ }^{(1)}$, \\ Pierre Raimbault ${ }^{(1)}$, \\ Luc Harvengt ${ }^{(3)}$, \\ Isabelle Bilger ${ }^{(1)}$, \\ Monique Guibert ${ }^{(1-4)}$
}

\section{Introduction}

One hundred years after the first epidemic of Dutch elm disease (DED), forty af ter the second and thirty after the launch of conservation programmes, the time has come to take stock of the three species of Ulmus naturally present in France (Box 1) as well as the outcome of the conservation

(1) INRAE, UR EFNO, F-45290 Nogent-surVernisson (France); (2) Office National des Forêts, Pôle National des Ressources Génétiques Forestières, F-44290 Guémené-Penfao (France); (3) FCBA, Pole Biotechnology and Advanced Forestry, Forest-Wood Campus of Pierroton, F-33610 Cestas (France); (4) Retired.

\section{@ Cécile Joyeau (cecile.joyeau@inrae.fr)}

Received: Feb 10, 2019 - Accepted: Jan 21, 2020

Citation: Collin E, Rondouin M, Joyeau C, Matz S, Raimbault P, Harvengt L, Bilger I, Guibert $M$ (2020). Conservation and use of elm genetic resources in France: results and perspectives. iForest 13: 41-47. - doi: 10.3832/ifor3065-013 [online 2020-02-03]

(§) A French version of this article was published in Revue Forestière Française \#62017 and can be freely downloaded from http: / /irevues.inist.fr/revueforestierefrancai se. Minor changes were brought into the English version, Box 2 added and literature updated.

Communicated by: Alberto Santini

\begin{abstract}
Launched in 1987, the French National Programme for the Conservation of $\mathrm{Na}$ tive Elm Genetic Resources focused on the ex situ conservation of clones of adult field elms (Ulmus minor Mill.) survivors of the Dutch elm disease (DED) pandemic. It was later expanded to include the in situ dynamic conservation of populations of European white elm (U. laevis Pall.) and wych elm (U. glabra Huds.). The national collection contains 441 clones, partly characterized and evaluated in a European project. The pathological tests and experimental plantations did not reveal clones truly resistant to DED but provided material for the restoration of hedgerows. Two conservation units of white elm and one of wych elm were selected, enriching the pan-European EUFORGEN network for dynamic conservation of forest genetic resources. This programme provides feedback on genetic conservation strategies for forest trees in a health crisis. New partners are invited to make use of the scientific potential of the clone bank and experimental plots.
\end{abstract}

Keywords: Ulmus, Genetic Resources, Ex Situ Conservation, In Situ Conservation, France measures. On the first subject, Piou et al. 2018 show that the field elm (Ulmus minor Mill.) is in no way threatened with extinction in France, in spite of the fact that the aggressiveness of the pathogenic fungus Ophiostoma novo-ulmi Brasier has not diminished (Brasier \& Webber 2019).

This paper presents the results of the ex situ conservation actions carried out in France in favour of this species and summarizes the more recent in situ conservation measures undertaken for the European white elm (U. laevis Pall.) and the wych elm (U. glabra Huds.). It also makes recommendations for the use of the different types of genetic material available to French forest planters and concludes with perspectives on the scientific and practical use of the clone bank and experimental plots.

\section{Cloning of old elm survivors: ex situ collections}

It was in Lower Normandy in 1985-86 that a project was first designed and implemented to identify and clone the old "surviving" elms of this area very rich in field elms. This project, led by the Crepan environmental association with the support of Lemonnier nurseries, aimed to select and disseminate local elm clones with a higher tolerance to DED (Lemonnier \& Girard 2007, Rousseau \& Joly 2007). This initiative was relayed at the national level by CEMAGREF (renamed IRSTEA in 2012 and INRAE after merging with INRA in 2020) from 1987 , at the request of the Ministry in charge of the environment and with the constant support of the Ministry of Agriculture. At the end of its constitution, the national collection has amassed 441 clones, comprising 205 field elms, 107 Dutch elms (U. $x$ hollandica Mill.), 29 wych elms and 100 European white elms (Fig. 1). Its composition reflects the different phases of its creation (Tab. 1). Like other national collections managed by the Commission for Forest Genetic Resources (CRGF - Collin et al.
Box 1 - The three indigenous species of elms in France.

The field elm (Ulmus minor Mill.) is common everywhere in the plains and often recognizable by the corky ridges of its young twigs; its natural hybrids ( $U$. $x$ hollandica Mill.) with the wych elm are common and bear larger leaves of various forms.

The wych elm (U. glabra Huds.) is found mainly in mountain and hill forests; the terminal leaves of its vigorous shoots often bear 3 or 5 conspicuous long teeth at their apex.

The European white elm (U. laevis Pall.) is restricted to riparian and alluvial forests, though old roadside trees can occasionally be found. It can be easily recognized in spring by its fluttering flowers and samarae borne by a peduncle of between 1 to 2 $\mathrm{cms}$ in length. Its leaf buds are acute and dark-orange. With age, the roots form conspicuous buttresses at the base of the trunk. 


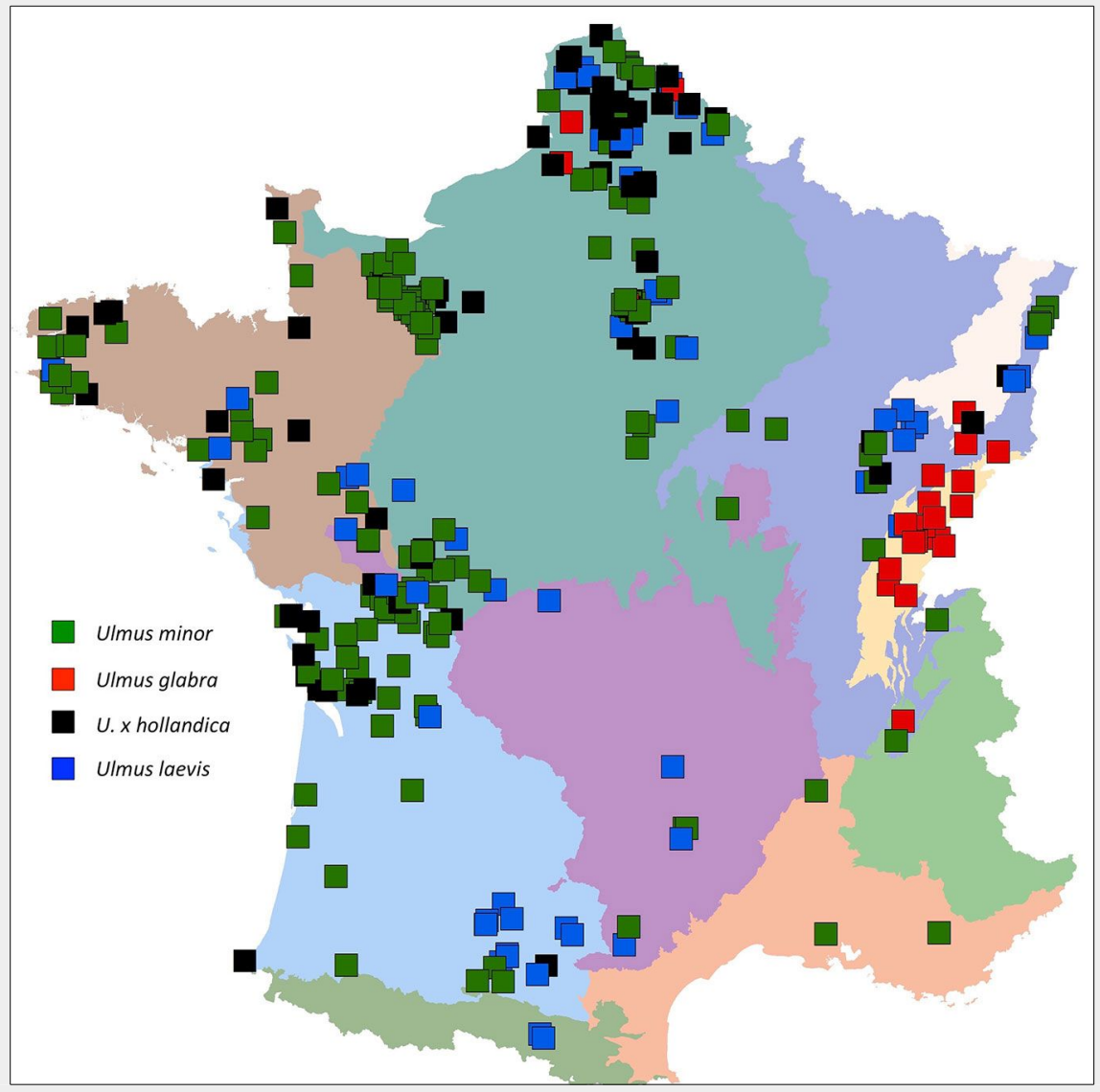

Fig. 1 - Origins of the clones in the national collection. Map background: Grandes Régions Ecologiques (Institut Géographique National 2011).

2012), it is kept at the nursery of the Pôle National des Ressources Génétiques Forestières (PNRGF) of the Office National des Forêts (ONF) in Guémené-Penfao (Loire-Atlantique). The clones are listed in the "register of basic materials for the ex situ conservation of forest genetic resources" by the Ministry of Agriculture. In addition, 181 clones from seven foreign collections have been conserved since 2000-2001 at Nogent-sur-Vernisson (Loiret) as part of the
Conservation of Elm Genetic Resources EUproject (RESGEN-78) to coordinate the conservation, characterization and evaluation of elm collections in nine European countries.

\section{Characterisation and evaluation of European elm clones}

The scientific management of a collection of plant genetic resources is based on the phenotypic (biometrics, phenology, etc.) and molecular characterization (DNA markers) of its components (clones, varieties, etc.). Another important step for collections of agricultural, horticultural or forestry interest is the evaluation of their components in terms of agronomic production or resistance to diseases or other adversities. In 1992, the University of ParisSud used isoenzymatic markers to characterize the elm clones already in collection. In 1995, the Institut National de la Recherche Agronomique (INRA) of Nancy started to test clones susceptibility to the pathogen of DED by artificial inoculation in nursery plantations. The markers revealed the large genetic diversity of the analysed samples (representing about 250 elms still alive in 1985) and little difference between the populations of the studied regions; they also rejected the hypothesis of hybridization between the European white elm and the two other European species (Machon et al. 1995, 1997). The pathological tests immediately showed that the level of resistance of the native European clones tested was very low compared with the cultivars (resistant clones obtained by crossing with Asian elm species) used as controls, but also that a large interclonal variability of resistance nevertheless existed within the collection.

Ten years later, the European co-financing of the RESGEN-78 project made it possible to develop these initial works. INRA continued the evaluation of French clones by artificial inoculation, while other collections were being evaluated in participant countries following a common experimental protocol. Several clones were noted for their comparatively greater resistance (Pinon et al. 2005, Solla et al. 2005). The molecular characterization of a representative sample of the collections was carried out by two teams: one in Scotland, on DNA of bi-parental origin extracted from the nucleus of the cells, the other at the ONF Orleans, on DNA of maternal origin, extracted from chloroplasts. The first approach, ap-

Tab. 1 - Phases of constitution of the national collection. The first two phases (1987-1994) form the basis of the collection; they aimed to collect a large sample of elms from four regions, including three rich in field elms and a fourth, more forested and continental, where the three elm species are present. The following phases, of decreasing size over time, were intended only to improve the representation of the national collection.

\begin{tabular}{lll}
\hline $\begin{array}{l}\text { Years } \\
\text { (Number of clones) }\end{array}$ & Regions (Number of clones) & Remarks \\
\hline 1987 (74) & Basse-Normandie (74) & $\begin{array}{l}\text { Acquisition of clones already obtained by Crepan and Lemonnier } \\
\text { nurseries }\end{array}$ \\
\hline 1988 to 1994 (197) & $\begin{array}{l}\text { Poitou-Charentes (67), Franche-Comté } \\
\text { (44), Picardie + Nord-Pas-de-Calais (86) }\end{array}$ & $\begin{array}{l}\text { Large regional campaigns to inventory elms and collection of cuttings } \\
\text { organised by Cemagref and a regional forest service (SERFOB or } \\
\text { DRONF) with the participation of other institutional actors } \\
\text { (conservatories, ...) and volunteer informants solicited by the press } \\
\text { (farmers ...) }\end{array}$ \\
\hline 1990 to 1998 (135) & $\begin{array}{l}\text { Seine-et-Marne (35), Plaine d'Alsace } \\
\text { (19), Grande Chartreuse (5), } \\
\text { Bretagne/Pays-Loire (36), Midi-Pyrénées } \\
\text { (35), Centre-Bourgogne (5) }\end{array}$ & $\begin{array}{l}\text { Targeted collection of cuttings with the support of an informant } \\
\text { (forester, naturalist) who contacted Cemagref after having inventoried } \\
\text { elms locally }\end{array}$ \\
\hline $\begin{array}{l}\text { Centre-ouest/nord-ouest (21), Centre } \\
\text { (4), Alpes (2) et sud de la France (8) }\end{array}$ & $\begin{array}{l}\text { Opportunistic collection of grafts or cuttings, usually with the support } \\
\text { of an informant (ethnobotanist, forester) who spotted one or several } \\
\text { remarkable elms }\end{array}$ \\
\hline
\end{tabular}


plied to 535 clones, confirmed that the elm genetic diversity is large but weakly structured geographically. It proved also helpful in the determination of hybrids between field elm and wych elm, and with the Siberian elm (U. pumila L. - Goodall-Copestake et al. 2005). The second approach, applied to more than 850 clones shed light on the pattern of re-colonization of Europe by the elms after the last glaciation. It also reinforced the hypothesis of the nativeness of the European white elm in southwest France. The bud burst phenology of the clones of several national collections was recorded for three years, which made it possible to characterize each clone according to this criterion and to calculate for each species the thermal parameters of bud burst (Ghelardini et al. 2006). Other observations of ornamental interest, and susceptibility to Elm Yellows ("Candidatus Phytoplasma ulmi") were also made.

\section{A network of experimental plantations}

After the completion of the European project, the French programme moved more towards the dynamic conservation of in situ populations while continuing the evaluation of the clones of the national collection. Artificial inoculation tests were continued at Guémené-Penfao in partnership with the Italian RESGEN-78 project team, while experimental plantations (field hedgerows or monospecific plots) were established with numerous partners, mainly in western France. In both hedges and plots, the elms were planted at least five metres apart (Fig. 2), experimental protocol ensuring an equal distribution of clones throughout the plantation, at least five ramets per clone in hedges, and ten in the plots. In the earliest trial (Fig. 3b), $75 \%$ of the field elms studied were already contaminated by DED, which makes it possible to evaluate their reaction: death, recurrence of symptoms or remission. The other plantations (Fig. 3a and Fig. 3c) were less affected but provide more information each year. The data collected in the artificial inoculation tests and in the plantations enabled IRSTEA to select eight clones of field elm, including six French and two others, which were made available to forest nurseries in 2017 (Tab. 2). However, uptake of this material by nurseries was very limited because it was not resistant enough to DED. Unlike resistant hybrid cultivars, the selected clones are elms with typical characteristics of the field elm (small leaves, corky twigs). These clones show only moderate and unstable resistance to DED, with

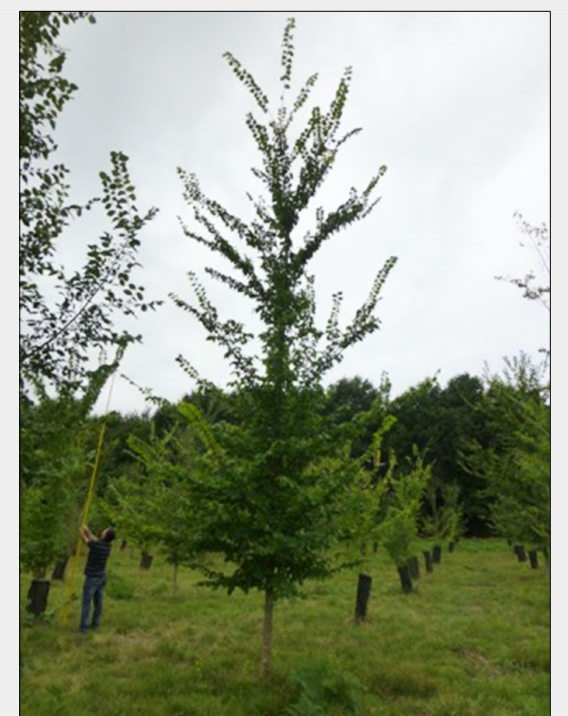

Fig. 2 - Experimental elm plantation of Saint-Herblain, near Nantes, Loire-Atlantique (Photo: Irstea E. Collin, 2016).

some individuals of a clone succumbing to the disease while others of the same clone recover or experience remission. "Christine Buisman", of Spanish origin, is the most DED-resistant of the selected clones. It has
Fig. 3 - Impact of DED in 2017 in experimental plantations older than 2011. These results concern clones of field elm or natural hybrids be-

tween field elm and wych elm. Improved cultivars (e.g., LUTECE) and

European white elm clones were not considered, as well as plants less than $3 \mathrm{~m}$ (generally unattractive to the vectors of DED).

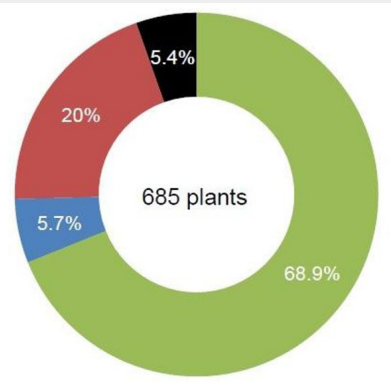

a) all plantations 14 trials - 2002 to 2010 43 clones

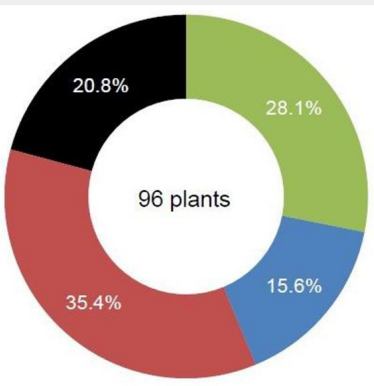

b) oldest test

Nogent / V. (45) - 2002 14 clones

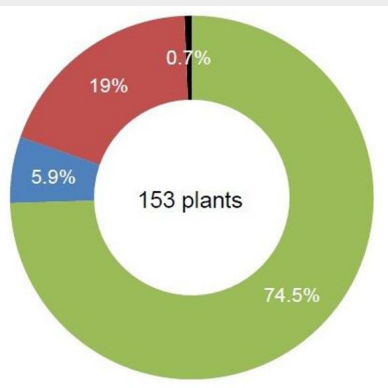

c) largest plot

St-Herblain (44) - 2007 21 clones

symptomatic

in remission still healthy

Tab. 2 - Clones of field elm made available to French forest nurseries in 2017. The first six clones belong to the French national collec tion, which is managed by the Commission for Forest Genetic Resources (CRGF). The last two are foreign acquisitions, chosen so as to extend the diversity of the geographical origins of the material made available.

\begin{tabular}{lllll}
\hline Short code & Full code & $\begin{array}{l}\text { Breeder or } \\
\text { maintainer }\end{array}$ & $\begin{array}{l}\text { Geographic origin } \\
\text { «département» }\end{array}$ & Notes \\
\hline F028 & FRA.ULS.0028 & CRGF (FR) & Calvados & - \\
\hline F077 & FRA.ULS.0077 & CRGF (FR) & (Basse-Normandie) & Unknown «département» \\
\hline F351 & FRA.ULS.0351 & CRGF (FR) & Finistère & - \\
\hline F470 & FRA.ULS.0470 & CRGF (FR) & Haute-Savoie & - \\
\hline F479 & FRA.ULS.0479 & CRGF (FR) & Gironde & - \\
\hline F501 & FRA.ULS.0501 & CRGF (FR) & (Charente-Maritime) & $\begin{array}{l}\text { Mother: clone FRA.ULS.0140 (Ch.-Marit.) } \\
\text { father: unknown (open progeny) }\end{array}$ \\
"Van Slycken” & “Jos Van Slycken” & INBO (BE) & Flanders (Belgium) & $\begin{array}{l}\text { Clone studied in the European project RESGEN-78; } \\
\text { released with the agreement of the breeder }\end{array}$ \\
\hline “Buisman" & “Christine Buisman” & Dorschkamp (NL) 1937 & Madrid (Spain) & $\begin{array}{l}\text { Cultivar obtained and distributed in the Netherlands } \\
\text { in 1937, from Spanish seeds; Royalty-free }\end{array}$ \\
\hline
\end{tabular}


Tab. 3 - Clone banks and cryopreservation: respective advantages and disadvantages. CEMAGREF and the nursery of Guémené-Penfao have almost exclusively used the softwood cuttings technique to massively clone and propagate the elms of the national collec tion. In recent years, grafting was very conveniently used to ensure opportunistic cloning of one or few elms in few copies.

\begin{tabular}{|c|c|c|}
\hline Stage & Clone banks (from softwood cuttings) & Cryopreservation \\
\hline $\begin{array}{l}\text { State of the preserved } \\
\text { material }\end{array}$ & $\begin{array}{l}\text { Whole plant, growing subject to the rhythm of the seasons } \\
\text { and interacting with its environment }\end{array}$ & $\begin{array}{l}\text { Dormant buds preserved in microtubes at } \\
-196^{\circ} \mathrm{C}\end{array}$ \\
\hline Introduction in collection & $\begin{array}{l}\text { Propagation by cuttings relatively easy for European white } \\
\text { elm and field elm. Risks of failure for wych elm }\end{array}$ & Easy and very inexpensive \\
\hline Maintenance in collection & $\begin{array}{l}\text { Maintenance and annual trimming }(<1.8 \mathrm{~m}) \text { essential (risk of } \\
\text { contamination by DED) }\end{array}$ & Easy and very inexpensive; without risk \\
\hline $\begin{array}{l}\text { Regeneration of whole } \\
\text { plants }\end{array}$ & $\begin{array}{l}\text { Easy propagation of all clones by herbaceous cuttings if the } \\
\text { clone stock is young; beyond ten years, the percentage of } \\
\text { rooting of cuttings of some clones can decrease very strongly, } \\
\text { or even become null }\end{array}$ & $\begin{array}{l}\text { Difficult and very expensive. In contrast, } \\
\text { plants grown in vitro can be easily further } \\
\text { propagated by horticultural cuttings }\end{array}$ \\
\hline Plant health & Risk of introduction and even spread of pathogens and pests & $\begin{array}{l}\text { No plant health risk; In addition, plants } \\
\text { grown in vitro are disease-free and are } \\
\text { therefore good sources of cuttings }\end{array}$ \\
\hline $\begin{array}{l}\text { Interest as a support for } \\
\text { studies and research }\end{array}$ & $\begin{array}{l}\text { Enables all kind of measurements and observations to be } \\
\text { made on a young tree. The elm clones have their own roots } \\
\text { and are not influenced by a rootstock }\end{array}$ & $\begin{array}{l}\text { Little interest except as a well-preserved } \\
\text { source of DNA and to refurnish destroyed or } \\
\text { contaminated material in the field }\end{array}$ \\
\hline
\end{tabular}

been planted in the Netherlands until the 1940 s and then abandoned because of its susceptibility to sea winds and Coral spot fungus (Nectria cinnabarina), a problem in the damp Dutch climate. It was propagated again by the CRGF in 2005 and used as a control clone in inoculation tests, where it demonstrated its value.

\section{Sustainably maintain and enhance the collections}

The Lower Normandy conservation project had been based on the hope of keeping its collection of clones free from DED on Chausey island (part of the Channel Islands), but this hope was soon dashed. The solution, chosen in 1987 for the national programme was that of a clone bank planted on CEMAGREF land, and that the elms would be periodically coppiced or trimmed annually to prevent them from reaching a height of more than $2 \mathrm{~m}$. Thus rendering them unattractive to the bark beetles, vectors of DED. In addition, the Afocel (currently FCBA) was in charge of cryopreservating buds in liquid nitrogen and developing the technique of regeneration of whole plants by in vitro meristem culture (Harvengt et al. 2004). A hundred clones of the national collection are currently cryopreserved together with 400 clones from seven other EU member countries. Time has confirmed the interest of these two complementary technical options, the respective advantages and disadvantages of which are presented in Tab. 3.

At the end of the constitution, characterization and evaluation phases of a collection, the question of its maintenance becomes a major concern, especially regarding clonal banks. The material constraints (i.e., need to clear the ground) and budget (i.e., maintenance and hedge-trimming costs) conspire to reduce the size of the clone banks when collections are no longer the subject of research and their maintenance no longer funded. The method conventionally adopted in this situation is to keep only the core of the collection, comprising elements representing the genetic diversity of the complete collection. The composition of the French elm core collection (195 clones) was defined according to multiple criteria of diversity (geography, environment, taxonomy, molecular markers, resistance to DED, ornamental or patrimonial value). A backup duplicate of this collection is already in place in Nogent-surVernisson together with the 181 clones of seven other European collections.

Another way to ensure the conservation of subsets of the collection is to establish seed orchards, possibly regionalized, to ensure the convenient supply of seeds of known and genetically diverse origin. Such an experimental orchard was established

\section{Box 2 - Forest genetic resources conservation methods.}

In situ conservation aims at maintaining a population in its natural environment, whereas ex situ conservation involves transferring individual plants or propagating material (seed, grafts, cuttings, etc.) into seed banks or clone collections (e.g., clone banks, cryopreservation tanks).

Static conservation aims at the preservation of the current set of genotypes, e.g., clones of interest for breeding or representative of the species genetic diversity over a portion of its range. In contrast, dynamic conservation seeks the genetic evolution of the conserved population and its adaptation to the changes of its environment; this requires enhancing its genetic diversity and facilitating generation turnover and natural selection.

in Nantes in 2015 by the PNRGF of Guémené-Penfao. Constituted by grafting onto DED-resistant rootstock (LUTECE ${ }^{\circledast}$ "Nanguen", an easily recognizable cultivar in case of graft rejection), it brings together about sixty clones mainly from the west of France.

\section{In situ dynamic conservation in France and in a pan-European perspective}

The long-term conservation of seed or clone collections belongs to a "static" conception of conservation (Box 2), as it is about preserving genetic resources in the adaptive state they were in when they were saved. However, for forest geneticists (Eriksson et al. 1993), the important thing is not to preserve the past but to prepare for the future by stimulating the process of adapting tree populations to changes in their environment. This "dynamic" concept underlies conservation programmes defined at the French (CRGF) and European (European Forest Genetic Resources programme, EUFORGEN) levels since the mid-1990s (Fady et al. 2012).

In situ dynamic conservation consists of managing natural populations (conservation units, CUs) by promoting the emergence and selection of new gene combinations. This requires allowing natural selection (the "motor" of adaptation) to act after maximizing the genetic diversity of the regeneration (the "fuel" of adaptation). The manager must therefore adopt dynamic silvicultural methods and ensure that the number of breeding trees is as large as possible, so as to facilitate pollen exchange within the stand and optimize seed genetic diversity. They must also create conditions conducive to the installation and protection of regeneration (Fady et al. 2012).

In France, in situ dynamic conservation is not a priority for the field elm, as it is still very abundant in the shrub layer and occa- 
sionally as seedlings, and also largely conserved ex situ. By contrast, it is perfect for the European white elm, whose natural populations are more affected by the destruction or the fragmentation of the riparian forests than by DED. This species is not very attractive to the beetles vectors of DED and many mature trees remain. In situ dynamic conservation of the wych elm, on the other hand, has proved difficult to implement in France. The populations of this species, which does not sucker and only resprouts with difficulty, are severely affected by DED. Seed trees succumb to DED, while browsing deer may compromise natural regeneration. Even when regeneration is abundant and successful, there remains the risk of a limited genetic basis (i.e., few breeding parents).

\section{In situ conservation units (CUs)}

Two CUs of European white elm were selected: the National Nature Reserve (RNN) of Val d'Allier, near Moulins, and the Ramier de Bigorre site on the banks of the Garonne river, downstream from Toulouse. These populations have been selected from a European-wide conservation perspective as both are at the limit of the range of this medio-European species (Collin \& Bozzano 2015). In Val d'Allier, more than 500 individuals over $5 \mathrm{~cm}$ in diameter at $1.30 \mathrm{~m}$ height were counted in 2002 along about $20 \mathrm{~km}$ along the river. It is a young population, with only about 100 trees over $20 \mathrm{~cm}$ in diameter. The mortality caused by DED is rather important but localized in some sectors. Flowering and seeding are abundant and of good quality but regeneration seems to be infrequent. The CU of Ramier de Bigorre (117 ha in total) comprises three sub-populations separated by a few kilometres. More than 700 individuals were counted, including 130 with a diameter over $20 \mathrm{~cm}$. DED is present but causes very little damage. The ancient presence of the European white elm is attested by the very large trees on the site. Saplings and thickets are abundant and prove that the population renewal is good in spite of the current scarcity of seedlings.

In both cases, the collaboration with the naturalists managing the site (Ligue pour la protection des oiseaux, Nature-Midi-Pyrénées) is excellent and testifies their interest in the dynamic approaches to the conservation of the genetic resources. The same goes for other sites assessed (e.g., RNN de Saint-Mesmin downstream from Orléans) where the populations of European white elm are closely monitored even if they do not have a CU status.

Only one wych elm CU was selected because large populations of this species with different age classes have become rare or are little known. From this point of view, the forest of Saint-Pé-de-Bigorre (HautesPyrénées) is an exception, with two narrow valleys where the wych elm is omnipresent mixed with lime tree and hazel. Elm can also be found disseminated on the slopes where it is mixed with beeches. A visit in 2016 revealed that the population remains abundant despite the mortality caused by DED. There are no data over a large sample of the population but, of 22 trees identified in 2007 and visited in 2016, $36 \%$ had succumbed to DED. The different age classes are well represented and very young seedlings have been found in various places, especially on the slopes. This population has been accepted as a CU despite its overlap with the Saint-Pé-de-Bigorre Integral Biologic Reserve because the elm can regenerate without human intervention in gaps caused by the frequent storm damage in the area.

\section{Planting elms in France? With which genetic resources?}

In France, there is an interest in the restoration of $U$. minor but, at the same time, planters' choice goes for cultivars highly resistant to DED. Several such cultivars are currently marketed in the country while only a few nurseries propagate material of local origin. The advantages and the respective uses of these different types of material should not be confused, knowing that the European native elms are not strongly resistant to DED and that the clones highly resistant to this disease are either Asian or only partially European (i.e., Eurasian hybrids - Martin et al. 2019).

Only highly resistant cultivars such as LUTECE $^{\circledR}$ "Nanguen" can be recommended for ornamental purposes in parks and on streets (Pinon \& Cadic 2007). In educational "natural" areas reconstructed with native European species only, one can use the clones of field elm listed in Tab. 2, provided that the public is informed about the effects of DED and area managers are prepared to lose some trees or to cut them to the stump to stop infection. European white elm can also be used without too much risk as it is less frequently affected by DED than the field elm.

Planting elm for timber production would be a risky gamble, especially because it is not known yet whether the wood of hybrid cultivars will ultimately be as prized as that of the field elm. Hedgerow elms could be pollarded and provide firewood or even fodder for livestock.

The plant material for the restoration of hedgerows or the conservation of biodiversity associated with elms is a matter of contention. Some planters play on the word "elm" and advocate the use of highly resistant cultivars, even if they are Asian or hybrids of European and Asian elm. This was the case in France in the 1990 s with the Resista ${ }^{\circledR}$ "Sapporo Autumn Gold" cultivar (Soltner 1992) and more recently in England with other cultivars planted to maintain populations of the white-letter hairstreak butterfly Satyrium W-album (Santini et al. 2011). Conversely, local plant certification requires the use of seed batches collected in at least three sites in the same region (http://www.fcbn.fr/vegetal-local-vrai es-messicoles). These two ideologically opposed attitudes raise the question of limits to be imposed on the intervention of man in gene flows into presumed natural populations. The observations we made in Nogent-sur-Vernisson in 2015, 2016 and 2017 suggest it would be appropriate to study the possible effect of Asian or hybrid cultivars on native genetic resources. The flowering periods of LUTECE $^{\circledR}$ "Nanguen" and Resista "Sapporo Autumn Gold" coincide in part with those of field elms and the seeds harvested from these cultivars produced viable seedlings (unpublished data). The adverse consequences of the introduction of Siberian elm (U. pumila L.) to Italy, Spain and the United States are well documented (see bibliography in Piou et al. 2018 and Martin et al. 2019).

In terms of gene flow, the use of seedlings of local origin is a prudent option, though possibly too cautious as it does not contribute to the enrichment of the local gene pool needed to facilitate adaptation to uncertain futures (Eriksson et al. 1993) such as the abiotic and biotic consequences of climate change. Mixing plants of several clones listed in Tab. 2 with seedlings of regional origin would locally increase the possibilities of genetic recombination and adaptation while providing controls of known limited tolerance to DED. Other clones from the national collection could also be used or, in a few years, seeds from experimental plantations or conservation orchards. Such inputs, provided they remain quantitatively small and genetically diverse, would not be a truly new practice for field hedgerows, which have been largely shaped by humans for centuries (Cox et al. 2014). More generally, Martin et al. 2019 advocate the use of native tolerant field elm clones in plantations aiming at restoring native elm populations and their ecological roles.

On the other hand, the genetic advantages and risks of intervening in riparian natural populations of elms need to be considered carefully. In France, the balance is unclear or negative in the case of field elm because its riparian populations are very large and able to maintain themselves with profuse resprouts and young mature trees. On the contrary, the balance is positive for small populations of European white elm, often fragmented and potentially threatened by genetic drift. In such cases, habitat restoration and dynamic conservation actions can be combined by planting seedlings from seeds harvested from all sub-populations of the original population.

\section{Perspectives}

As its main objectives have been reached, the static ex situ conservation component of the elm programme is now undergoing only light monitoring. The national collection has a wide genetic diversity and has been used as a support for numerous studies and for the dissemination of native 
plant material for the reconstitution of hedgerows. It does not need to be extended, especially since the ex situ conservation of the field elm no longer appears as necessary today as in 1985 (Piou et al. 2018) and the cloning of old elms, survivors of the epidemic, did not reveal clones truly resistant to DED. In addition, European white elm can be conserved in situ, while wych elm would be more relevant to ex situ techniques combined with dynamic approaches, such as seed cryopreservation or grafted seed-orchards in the scope of enriching the natural regeneration of conservation populations. The molecular characterization of the collection, too old and incomplete, needs to be renewed and completed with the more powerful markers recently developed for the elms.

The in situ component of the programme is solidly established for European white elm but a wych elm CU should be selected in the alpine massif, which would require extensive prospecting. The situation of this species deserves to be better studied in France, as well as the results of the conservation measures (mainly seed orchards) adopted in Germany and Central Europe.

As regards the clonal bank and experimental plots already in place, a light monitoring should be sufficient to preserve the potential of these plots as sources of knowledge and plant material. For example, the national collection may in its current form, provide the DNA of a large sample of elm trees from Basse-Normandie and Poitou-Charentes that were adults or very old in 1985. It would be interesting and easy to compare this old sample with a new sample taken from the same municipalities and thus objectively quantify the impact of DED on the genetic diversity of the elm populations of these two regions. Such a study could not be conducted with the same precision from the core collection. This should be taken into consideration when the Guémené-Penfao clone bank will have to be renewed and reduced. The reduction should have to relate to the number of copies of each clone rather than to the elimination of the material out of core collection, and even also out of the national collection (i.e., foreign clones and old cultivars).

In fact, the cost / benefit ratio of the maintenance of these plots can also be improved by a better use of their botanical and experimental capital, this thanks to the development of new partnerships, e.g., with universities. The progress in the systematics, genetics, pathology and phenology of the elms that the collections made possible fifteen years ago is considerable. It is clear that these same collections can lead to new advances in knowledge through current research tools (see review in Martin et al. 2019). These advances can in turn stimulate the creation of varieties, and not only in terms of resistance to DED. CUs can be used as study sites for monitoring the demo-genetic dynamics of tree populations under health crisis conditions. Experimental plantations, thanks to the numerous repetitions of the same clone in different states (healthy, sick, recovered, dead) provide exceptional opportunities to study the mechanisms of resistance to the pathogen. The oldest could already also enable the study of possible gene flow between two improved cultivars and several native clones.

In practical terms, these plots can also constitute sources of plant material, and not only by vegetative propagation. Seeds can probably be harvested in a few years in the plantations of Saint-Herblain (Loire-Atlantique) and Banneville-sur-Ajon (Calvados), and possibly also in the grafted conservation orchard in Nantes.

The emergence of new projects and partnerships requires a durable and easily accessible archiving of data (work in progress at (RGF), but also that the existence of plots and datasets is widely known to potential partners. We hope this publication will help. Indicators compiled regularly at the French level (Indicateurs de Gestion Durable des Forêts, Observatoire National de la Biodiversité, etc.) provide information on the development of national collections and in situ conservation networks. Like the 100 or so other French CUs, the three elm CUs are referenced among the 3300 CUs presented on the EUFORGEN website (http://www.euforgen.org/species/). Information on the elm collection and how to access the material can be supplied by the corresponding author or by the EUFORGEN national coordinator (http://www.euforgen .org/member-countries/france/).

\section{Conclusion}

The national programme for the conservation of genetic resources of native elms was born of a political will at a time when the second epidemic of DED swept the French landscapes. It has evolved in step with the progress of plant genetic resources conservation methods, firstly through the European Union's RESGEN programme for the characterization and evaluation of ex situ collections, and then under the influence of the dynamic conservation approaches advocated by the EUFORGEN pan-European programme. It has brought together more than 400 ex situ clones and selected three populations for in situ conservation. Thanks to numerous French and foreign scientific partnerships, it has spawned numerous scientific publications. Its practical outputs for forestry and conservation are not limited to the supply of indigenous plant material. It has called for a more cautious and pragmatic approach of elm species and varieties determination (Collin 2007) and helped to unify habitat, species and genetic conservation.

It is now time to learn the lessons of this prolonged programme. This will provide useful feedback to the working groups of the CRGF which reflect on the conservation strategies to adopt in case of a health crisis (e.g., ash dieback disease, new pest and diseases and parasites in relation with climate change, etc.) as well as for the economic evaluation of different conservation options. It is now important to disseminate information about the botanical capital and the facilities available, and seek partners wishing to use them.

\section{Acknowledgments}

The programme could not have developed without the financial support of the French Ministry of Agriculture, the AgriGenRes 009 programme of the European Commission (GenRes project CT96-78), and Plan Loire Grandeur Nature (Conservation of European white elm populations).

The authors thank C. Joly (Crepan), G. Philippe (Irstea) and the anonymous referees for the improvements made to the French and English manuscripts; A. Brookes and T. Fenning for their kind linguistic assistance, as well as many colleagues for their assistance with the elms.

The CU selection and the Saint-Herblain planting were carried out with the support of the ONF, the LPO, Nature-Midi-Pyrénées and J. Rieffel Agriculture School.

The historical work in the animation of the elm programme by D. Terrasson and G. Deboisse, the scientific contributions of INRA (J. Pinon, M. Arbez), University ParisSud (N. Machon), of the Forest Tree Genetics Conservatory of the ONF (B. Musch, B. Le Guerroué) and the ENGREF Arboretum des Barres (D. Piou) are also gratefully acknowledged.

Finally, deep gratitude is expressed to the diverse people, far too many to mention by name, who have also assisted with the work presented in this paper.

A French version of this article was published in Revue Forestière Française \#6-2017 and can be freely downloaded from http://irevues.inist.fr/revueforestierefrancai se. Minor changes were brought into the English version, Box 2 added and literature updated.

\section{The authors}

EC has led the French elm conservation programme from 1992 to 2018, after IB and before MG; $\mathrm{CJ}$ is responsible for the monitoring of CUs and the national elm collection; SM is in charge of maintaining the collection of European elms and the French core collection at Nogent/V.; MR is the manager of the elm clone bank at Guémené-Penfao and has propagated the plant material planted in inoculation tests and field tests; LH has carried out elm cryopreservation, in vitro propagation and is in charge of maintaining the cryopreserved collection; PR has performed the analysis of the experimental plantations.

\section{References}

Brasier C, Webber JF (2019). Is there evidence for post-epidemic attenuation in the Dutch elm disease pathogen Ophiostoma novo-ulmi? Plant Pathology 68 (5): 921-929. - doi: 10.1111/ppa.130 
22

Collin E (2007). Les ormes européens, des espèces mal connues [The European elms, illknown species]. Forêt-entreprise 175: 11-14. [in French]

Collin E, Le Bouler $\mathrm{H}$, Forestier O, Huvelin JP, Rondouin M, Brahic P, Bariteau M, Fady B, Oddou Muratorio S, Thévenet J, Dufour J, Villar M, Girard S, Harvengt L (2012). Conservation ex situ: collections statiques et valorisation dynamique [Ex situ conservation: static collections and dynamic valorization]. Rendez-vous techniques de l'ONF 36-37: 35-39. [in French] [online] URL: http://hal.archives-ouvertes.fr/ha |-00779754|

Collin E, Bozzano M (2015). Implementing the dynamic conservation of elm genetic resources in Europe: case studies and perspectives. iForest Biogeosciences and Forestry 8 (2): 143-148. doi: 10.3832/ifor1206-008

Cox K, Vanden Broeck A, Vander Mijnsbrugge K, Buiteveld J, Collin E, Heybroek HM, Mergeay J (2014). Interspecific hybridisation and interaction with cultivars affect the genetic variation of Ulmus minor and Ulmus glabra in Flanders. Tree Genetics and Genomes 10: 813-826. - doi: 10.1007/s11295-014-0722-4

Eriksson G, Namkoong G, Roberds J (1993). Dynamic gene conservation for uncertain futures. Forest Ecology and Management 62: 15-37. doi: 10.1016/0378-1127(93)90039-P

Fady B, Collin E, Ducousso A, Lefèvre F, Musch B, Fargeix J, Prochasson A, Reinhorn N, Villar M (2012). Conservation in situ des ressources génétiques forestières: stratégies, dimensions nationale et pan-européenne [In situ conservation of forest genetic resources: strategies, national and pan-European approaches]. Rendez- vous Techniques ONF 36 (37): 28-34. [in French] [online] URL: http://hal.archives-ouvertes.fr/ha |-00779677|

Ghelardini L, Falusi M, Santini A (2006). Variation in timing of bud-burst of Ulmus minor clones of different geographical origins. Canadian Journal of Forest Research 36 (8): 1982-1991. - doi: 10.1139/xo6-092

Goodall-Copestake WP, Hollingsworth ML, Hollingsworth PM, Jenkins GI, Collin E (2005). Molecular markers and ex situ conservation of the European elms (Ulmus spp.). Biological Conservation 122 (4): 537-546. - doi: 10.1016/j. biocon.2004.09.011

Harvengt L, Meier-Dinkel A, Dumas E, Collin E (2004). Establishment of a cryopreserved gene bank of European elms. Canadian Journal of Forest Research 34: 43-45. - doi: 10.1139/x03-193 Lemonnier M, Girard S (2007). Des professionnels impliqués dans la sauvegarde de l'orme: les pépinières forestières de Forges [A private company involved in elm safeguard: Forges forest nursery]. Forêt-Entreprise 175: 47-48. [in French]

Machon N, Lefranc M, Bilger I, Henry JP (1995). Isoenzymes as an aid to clarify the taxonomy of French elms. Heredity 74 (1): 39-47. - doi: 10.103 8/hdy.1995.5

Machon N, Lefranc M, Bilger I, Mazer SJ, Sarr A (1997). Allozyme variation in Ulmus species from France: analysis of differentiation. Heredity 78 (1): 12-20. - doi: 10.1038/hdy.1997.2

Martin JA, Sobrino-Plata J, Rodriguez-Calcerrada J, Collada C, Gil L (2019). Breeding and scientific advances in the fight against Dutch elm disease: will they allow the use of elms in forest restoration? New Forests 50: 519. - doi: 10.1007/ s11056-018-9645-5
Pinon J, Cadic A (2007). Les ormes résistants à la graphiose [DED resistant elm cultivars]. ForêtEntreprise 175: 37-41.

Pinon J, Husson C, Collin E (2005). Susceptibility of native French elm clones to Ophiostoma novo-ulmi. Annals of Forest Science 62: 689-696. doi: 10.1051/forest:2005066

Piou D, Benest F, Collin E (2018). Est-il possible de tirer des enseignements des introductions anciennes? L'exemple de la graphiose de l'orme [Are there any lessons to be learnt from long-standing introductions of pathogens? The case of Dutch Elm Disease]. Revue Forestière Française 70 (6): 621-637. [in French] - doi: $10.4267 / 2042 / 70312$

Rousseau J, Joly C (2007). La graphiose en Basse-Normandie depuis 20 ans [20 years with DED in Lower-Normandy]. Forêt-Entreprise 175: 26-28.

Santini A, Pecori F, Pepori A, Brookes A (2011). "Morfeo" Elm: a new variety resistant to Dutch Elm Disease. Forest Pathology 42 2: 171-176. doi: 10.1111/j.1439-0329.2011.00737.x

Solla A, Bohnens J, Collin E, Diamandis S, Franke A, Gil L, Buron M, Santini A, Mittempergher L, Pinon J, Vanden Broeck A (2005). Screening European elms for resistance to Ophiostoma novo-ulmi. Forest Science 51 2: 134-141. [online] URL: http://academic.oup.com/forestscience/ar ticle/51/2/134/4617585

Soltner D (1992). L'orme est de retour: autour de la maison, de la ferme, du village et des champs [The elm is back: by the house, farm, village and fields]. Sciences et techniques agricoles, Sainte-Gemme-sur-Loire, France, pp. 16. [in French] [online] URL: http://dialnet.unirioja.es/ servlet/articulo?codigo $=3529349$ 